\title{
Use of Microalgae for Advanced Wastewater Treatment and Sustainable Bioenergy Generation
}

\author{
Jae-Hoon Hwang, Jared Church,' Seung-Jin Lee, 2,3 Jungsu Park, and Woo Hyoung Lee ${ }^{1, *, \uparrow}$ \\ ${ }^{1}$ Department of Civil, Environmental, and Construction Engineering, University of Central Florida, Orlando, Florida. \\ Departments of ${ }^{2}$ Earth and Resource Science and ${ }^{3}$ Computer Science, Engineering \& Physics, University of Michigan-Flint, Flint, Michigan. \\ ${ }^{4}$ Water Quality Research Center, Korea Water Resources Corporation, Daejeon, Korea.
}

Received: March 16, $2016 \quad$ Accepted in revised form: June 30, 2016

\begin{abstract}
Given that sustainable energy production and advanced wastewater treatment for producing clean water are two major challenges faced by modern society, microalgae make a desirable treatment alternative by providing a renewable biomass feedstock for biofuel production, while treating wastewater as a growth medium. Microalgae have been known to be resilient to the toxic contaminants of highly concentrated organic wastewater (e.g., organic nitrogen, phosphorus, and salinity) and are excellent at sorbing heavy metals and emerging contaminants. Economic and environmental advantages associated with massive algae culturing in wastewater constitute a driving force to promote its utilization as a feedstock for biofuels. However, there are still many challenges to be resolved which have impeded the development of algal biofuel technology at a commercial scale. This review provides an overview of an integrated approach using microalgae for wastewater treatment, $\mathrm{CO}_{2}$ utilization, and biofuel production. The main goal of this article is to promote research in algae technologies by outlining critical needs along the integrated process train, including cultivation, harvesting, and biofuel production. Various aspects associated with design challenges of microalgae production are described and current developments in algae cultivation and pretreatment of algal biomass for biofuel production are also discussed. Furthermore, synergistic coupling of the use of microalgae for advanced wastewater treatment and biofuel production is highlighted in a sustainability context using life cycle analysis.
\end{abstract}

Keywords: bioenergy; biofuel; biomass; microalgae; nutrient recovery; wastewater

\section{Introduction}

$\mathbf{T}$ HERE IS AN INCREASING DEMAND for securing sustainable energy and clean water using innovative technologies, which can improve energy efficiency, mitigate greenhouse gas (GHG) emissions, and produce clean and safe water with less energy consumption. In recent years, the use of liquid biofuels in the transport sector has shown rapid global growth, driven mostly by policies focused on achieving energy security and mitigation of GHG emissions (IEA, 2007a).

First-generation biofuels, which have now attained economic levels of production, are mainly extracted from food and oil crops, including rapeseed oil, sugarcane, sugar beet, and maize (FAO, 2008). It is projected that the growth in production and consumption of liquid biofuels will continue, but their impacts toward meeting overall energy demands in the transport sector will remain limited due to competition with food production, regionally constrained market structures,

*Corresponding author: Department of Civil, Environmental, and Construction Engineering, University of Central Florida, 12800 Pegasus Dr. Suite 211, Orlando, FL 32816-2450. Phone: +1 407 823 5304; Fax: +1 407823 3315; E-mail: woohyoung.lee@ucf.edu ${ }^{\dagger}$ Member of AEESP. and a lack of well-managed agricultural practices in emerging economies (IEA, 2007b). Second-generation biofuels produce fuels from dedicated energy crops, rather than from food crops (Moore, 2008); however, technology for conversion of these fibrous feedstock has not yet reached the scale for commercial exploitation (FAO, 2008) and large amounts of land is still needed.

Microalgae-based biofuels, now considered the third generation of biofuel, can make a significant contribution to meeting primary energy demands by using nonarable land. Cultivated in brackish and wastewater, microalgae biofuel production does not compromise the production of food crops (Chisti, 2007; Dismukes et al., 2008). Microalgae are capable of rapid growth under light, which fosters oil productivity that exceeds the yields of the best oilseed crops (e.g., $12,000 \mathrm{~L} /$ ha biodiesel yield for microalgae compared to 5,950 biodiesel yield for oil palm) (Schenk et al., 2008; Dragone et al., 2010). They can also produce valuable coproducts such as carbohydrates, proteins, and residual biomass, which may be used as fertilizer (Metting, 1996) or fermented to produce ethanol or methane (Hirano et al., 1997).

Microalgae are capable of photobiological production of biohydrogen (Ghirardi et al., 2000). The combination of 
potential biofuel production, biohydrogen production, and biotreatment of wastewater emphasizes the potential applications of microalgae. Downstream processes for microalgalbased biofuel production are receiving increasing attention, which contributes to $60 \%$ of the total biodiesel production cost (Kim et al., 2013). It is necessary to reduce the downstream costs to ensure the economic feasibility of microalgalbased biofuel production. Despite inherent potential as a biofuel resource, there are still many challenges to be resolved which have impeded the development of algal biofuel technology at a commercial scale.

This review outlines state-of-the-art technologies and methods for biofuel production from microalgae used in wastewater treatment. The present communication highlights the process train for biofuel production from algae used in wastewater, which includes cultivation, harvesting, and biofuel production. It also seeks to identify knowledge gaps within each area, which can be targeted for focused research and innovation for sustainable algae-based biofuel technologies.

\section{Wastewater Treatment and Algal Biofuel Technology}

Wastewater treatment systems using microalgae represent a low-cost and environment-friendly wastewater treatment alternative when compared to conventional wastewater treatment processes (Liu et al., 2013). Algae's nutritional and chemical requirements can offer opportunities for advanced bioremediation and biofuel production by integrating industrial and municipal utilities with algae systems for a more holistic use of urban resources. For example, integrated algal wastewater treatment systems are able to capture $\mathrm{CO}_{2}$ from power plants and remove nitrogen $(\mathrm{N})$ and phosphorus $(\mathrm{P})$ from wastewater, while cultivating algae for biofuel production (Fig. 1). Recent studies emphasize four benefits of integrated algal systems: (1) effective $\mathrm{CO}_{2}$ filters, which utilize $\mathrm{CO}_{2}$-rich exhausts for algae growth in a sustainable way; (2) advanced biological wastewater treatment using the ability of algae to utilize $\mathrm{N}$ and $\mathrm{P}$ containing wastewater as an ecological wastewater treatment practice; (3) biofuel production given that algae can accumulate $20-70 \%$ lipid as part of their biomass; and (4) production of other valuable products, including carbohydrate, proteins, vitamins, and pigments for use as fertilizer or pharmaceutical applications. These four benefits promote the utilization of high nutrient resources for cost-effective algae cultivation. Pilot-scale algal bioreactors used for biofuel production already show lower GHG emissions than petroleum and other bioenergy benchmarks; there are still limitations that need to be addressed (Lundquist et al., 2010; Liu et al., 2013).

\section{Algal cultivation in wastewater}

Algal cultivation trends are highly dependent on economic factors with the goal of producing large amounts of lipids and biomass at low cost. Table 1 illustrates trends in algal cultivation research by focusing on operational parameters that can have large impacts on the costs of algal cultivation. Parameters like $\mathrm{pH}$, temperature, carbon source, and light intensity are now well understood and should be considered when designing algal cultivation processes. In general, algal wastewater cultivation processes should be operated like any biological wastewater treatment system. Large variations in temperature and $\mathrm{pH}$ can hinder algal growth. Nutrients found in most wastewaters should be sufficient for algal growth; however, desirable lipid production can be induced by nutrient control (e.g., P depletion). Other components like trace metals or silicon can also be utilized to improve lipid content. Inorganic carbon concentration is important to monitor for proper autotrophic cultivation and $\mathrm{pH}$ control. Salinity plays a large role in algal cultivation; however, salinity may only need to be considered with certain irregular waste streams (e.g., concentrate from desalination). Table 2 summarizes key operational parameters for algae cultivation. In addition, algae cultivation reactors have direct impacts on costs of cultivation and have been extensively studied for tradeoffs between cost and algae purity and lipid content. Open air, closed, and biofilm systems are commonly used reactors for cultivation and are discussed in more detail below.

Open air systems. Open air algal cultivation allows for small capital investments, free solar energy, and low energy for mixing. Open air systems are also vulnerable to contamination and only suitable for mixed culture cultivation. They also provide no control over temperature and lighting,

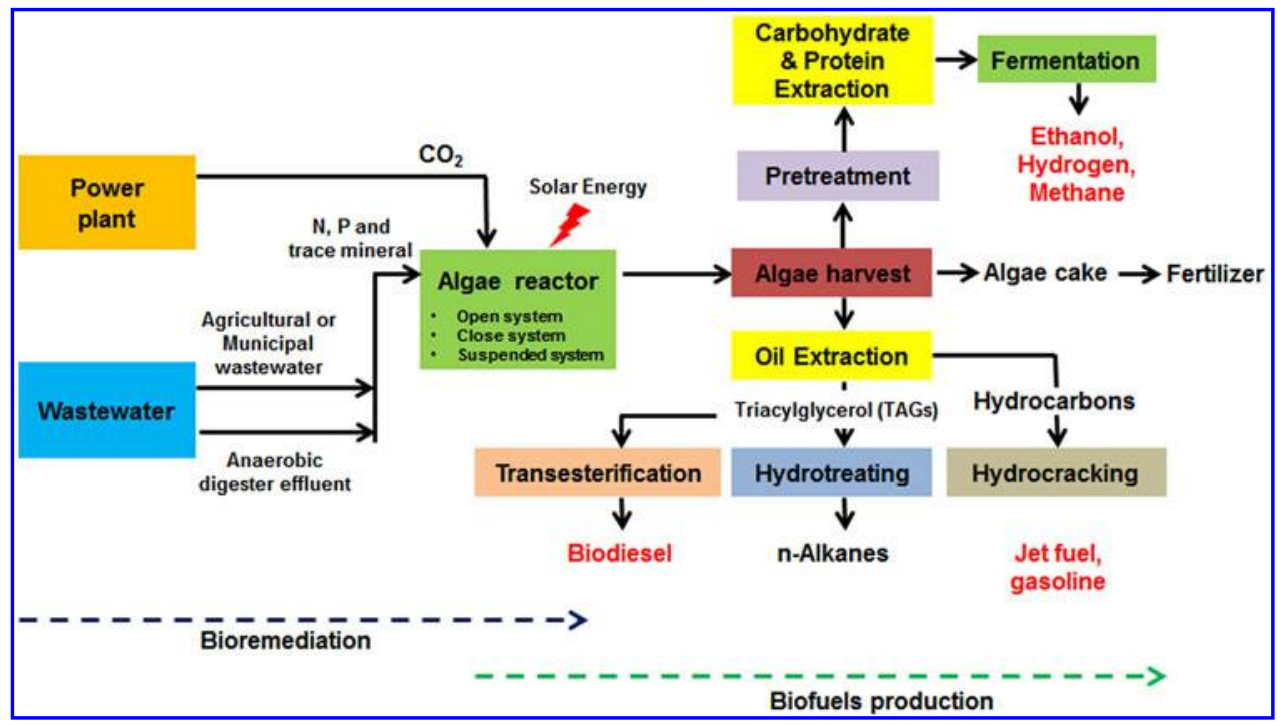

FIG. 1. Schematic of an integrated algal culture system for bioremediation and biofuel production. 


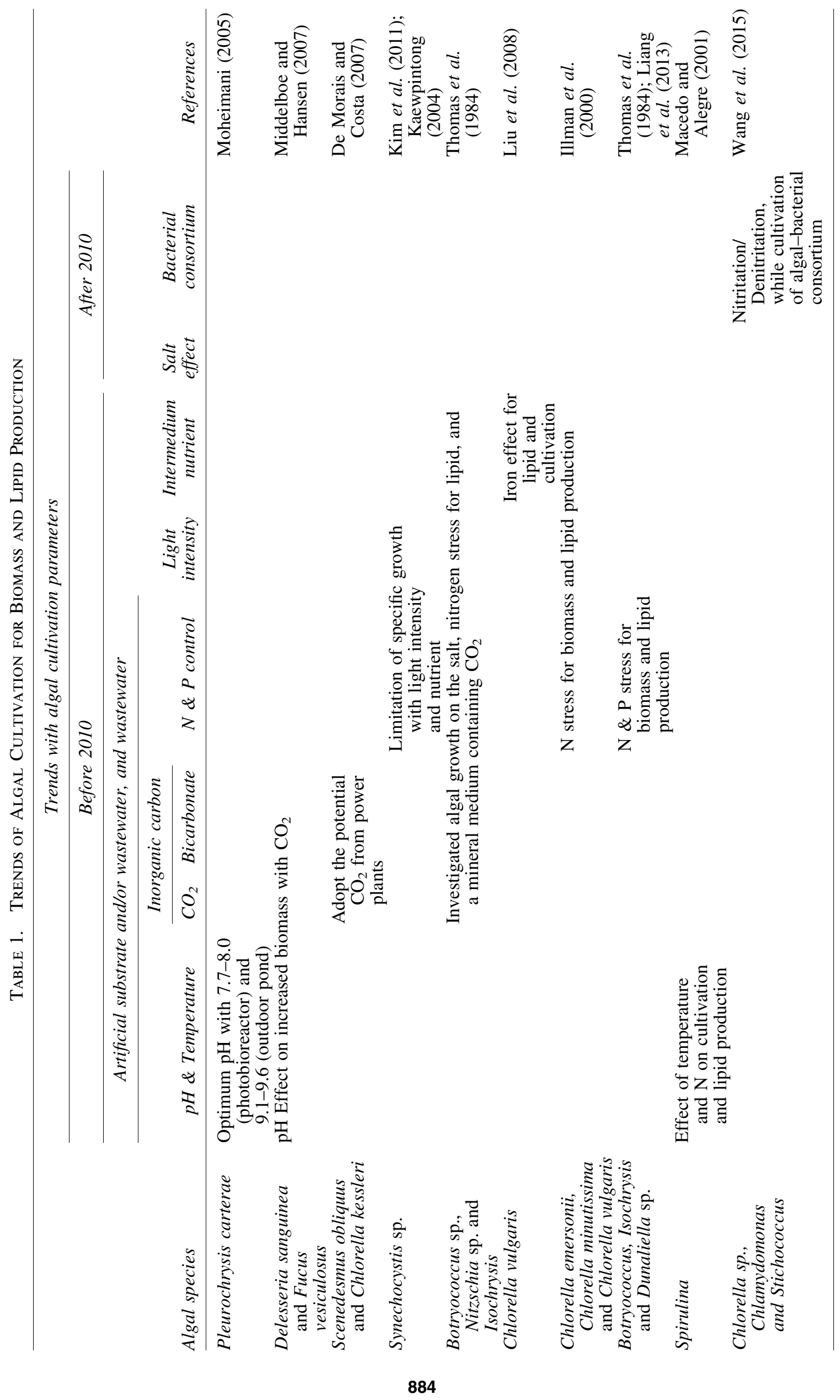


Table 2. Key Operational Parameters for Algal Cultivation

\begin{tabular}{|c|c|}
\hline Key operational parameters & Description \\
\hline Temperature & $\begin{array}{l}\text { Typical optimum temperature is between } 25 \text { and } 30^{\circ} \mathrm{C} \text { for algal cultivation } \\
\text { (Mehlitz, 2009). } \\
\text { Temperature has a large impact on growth rate. } \\
\text { Possible culture loss when exceeding the optimum temperature by more } \\
\text { than } 4^{\circ} \mathrm{C} \text { (Moheimani, 2005). }\end{array}$ \\
\hline $\mathrm{pH}$ effect & $\begin{array}{l}\text { Higher photosynthetic activity can increase } \mathrm{pH} \text {. } \\
\text { Rising } \mathrm{pH} \text { can be regulated by the addition of } \mathrm{CO}_{2} \text {. } \\
\text { Neutral } \mathrm{pH} \text { is favorable, but } \mathrm{pH} \text { as high as } 10 \text { and as low as } 4 \text { are tolerable } \\
\text { by some species (Moheimani, 2005). }\end{array}$ \\
\hline Inorganic carbon effect & $\begin{array}{l}\mathrm{CO}_{2} \text { and } \mathrm{HCO}_{3}^{-} \text {act as an inorganic carbon source for microalgae. } \\
\text { Dissolved inorganic carbon can be supplied from flue gas to save money and } \\
\text { increase growth rates (De Morais and Costa, 2007; Van Den Hende et al., 2011). } \\
\text { Flue gas quality is important when using power plants as an inorganic carbon } \\
\text { source (algae are sensitive to NOx and SOx). }\end{array}$ \\
\hline $\mathrm{N}$ and $\mathrm{P}$ ratio & $\begin{array}{l}\text { The optimum } \mathrm{N}: \mathrm{P} \text { ratio is between } 5: 1 \text { and } 10: 1 \text { for microalgae growth. } \\
\text { Improvement of lipid accumulation with decreasing } \mathrm{N} \text { and } \mathrm{P} \text { concentration in } \\
\text { microalgae (Shama et al., 2012; Liang et al., 2013). } \\
\text { Reduced biomass growth with decreasing } \mathrm{N} \text { and } \mathrm{P} \text { concentration. }\end{array}$ \\
\hline Intermedium nutrient & $\begin{array}{l}\text { Trace metals and other trace elements (e.g., silicon deficiency) can have } \\
\text { large impacts on microalgae growth and lipid production (Griffiths and } \\
\text { Harrison, 2009). } \\
\text { Iron supplementation affects lipid content and growth in C. vulgaris (Liu et al., 2008). } \\
\text { Heavy metals and nanoparticles can inhibit microalgae growth (Cheung et al., 1993). }\end{array}$ \\
\hline Light effect & $\begin{array}{l}\text { Strong illumination can inhibit the photosynthetic process (Kaewpintong, } \\
\text { 2004; Kim et al., 2015). } \\
\text { Surface area to volume ratio of } 2-8 \mathrm{~m}^{2} / \mathrm{m}^{3} \text { creates photoinhibition (Pulz, 2001). }\end{array}$ \\
\hline Salt effect & $\begin{array}{l}\text { Hot weather and high evaporation can cause a salinity affect. } \\
\text { High salinity can cause osmotic and cellular ionic stress due to selective ion } \\
\text { permeability of the cell wall (Moheimani, 2005; Salama et al., 2014). } \\
\text { High salinities can increase lipid content of some microalgae species. }\end{array}$ \\
\hline
\end{tabular}

which limit locations and times of the year open cultivation can be used (Kumar et al., 2015). In general, there are four major open systems for algal cultivation using wastewater; shallow big ponds, tanks, circular ponds and High Rate Algal Ponds (HRAP). (Kumar et al., 2015). HRAPs are commonly used to grow algae in wastewater and were first proposed by Oswald and Golueke (1960) as a way for economical algae biomass cultivation. They are still used by wastewater treatment plants as part of an advanced pond system, comprising anaerobic digestion pits, HRAPs, algal settling ponds, and maturation ponds in series (Park et al., 2011). HRAPs have not been as widely applied as facultative ponds, but with increasing regulatory pressure to remove nutrients and subsequent recognition of algae's potential as a renewable energy source, it is likely that HRAPs will be more widely applied in the future (Park et al., 2011). A recent full-scale example of HRAPs being used for wastewater treatment and biomass production is the Cambridge WWTP in North Island, New Zealand, where two 1-ha HRAPs were constructed to treat up to $1,500 \mathrm{~m}^{3}$ day $^{-1}$ of wastewater (Craggs et al., 2015).

Closed systems. Microalgae can be grown in photobioreactors (PBRs), where parameters like lighting, gas exchange, and mixing can be systematically controlled. PBRs offer a reduced contamination risk, which allows for cultivation of monocultures. The scale-up of PBRs have been proven difficult and costly. In particular, closed PBRs tend to overheat and without thermoregulation, temperatures can reach lethal levels. Attempts have been made to address thermal regulation issues; however, these solutions lead to higher construction and operation costs and negatively impact the environmental footprint (Pruvost et al., 2016). PBRs also have problems with dissolved oxygen (DO) build up, particularly at large scales. Air sparging can help remove DO, but adds to construction and energy costs. A recent study evaluated using perfluorocarbon nanoemulsions as oxygen scavengers and showed promising results (Lee and Yeh, 2015). Many designs of PBRs have been introduced to improve cultivation and reduce costs. The most common configurations include tubular systems, flattened plate-type systems, and ultrathin immobilized configurations (Pulz, 2001).

Biofilm systems. Algal biofilm systems for wastewater treatment and biomass production are less common than suspended algal production systems, but have drawn attention due to their growth platform addressing the issues of biomass harvesting commonly associated with mass algal cultivation. Algal "disks," rotating algal biofilm reactors, and algal turf scrubbers have been studied on bench (Kesaano and Sims, 2014) and pilot scales (Mulbry et al., 2008; Christenson and Sims, 2012) with promising results. However, successful integration of algal biofilms into wastewater treatment processes for nutrient 
removal is still limited by the lack of information on system performance, sustainability, and economic validity at a full scale (Kesaano and Sims, 2014).

\section{Algae for nutrient removal in wastewater}

In most conventional wastewater treatment operations, microorganisms require large amounts of oxygen to degrade organic material biochemically. Aeration devices use a large amount of electrical power with $45-75 \%$ of plant energy costs (Rosso et al., 2008) and impose a significant financial burden. Algae have been used extensively in wastewater treatment, either in conventional waste stabilization ponds or high-rate algae ponds, as a means to supply oxygen at a fraction of the energy required by mechanical aeration. Algae also play an important role in nutrient removal and recovery. A major requirement of utilities is to remove nitrogen $(\mathrm{N})$ and phosphorus $(\mathrm{P})$ from wastewater to prevent eutrophication of downstream rivers or lakes. The removal of $\mathrm{N}$ and $\mathrm{P}$ has been performed using nitrifying/denitrifying bacteria and phosphate-accumulating organisms, respectively; however, the design of the nutrient removal processes is relatively sensitive to receiving wastewater characteristics and additional organic carbon may be required for denitrification. However, microalgae have been shown to be resilient in wastewaters toxic to other organisms and use $\mathrm{CO}_{2}$ as inorganic carbon (Richards and Mullins 2013). The $\mathrm{CO}_{2}$ consumption by algae can increase $\mathrm{pH}$ in the bulk, resulting in $\mathrm{NH}_{3}$ volatilization and phosphate precipitation (Pittman et al., 2011; Kesaano and Sims, 2014). A study by Aslan and Kapdan (2006) found that a $C$. vulgaris can completely remove the initial $21 \mathrm{mg} / \mathrm{L}$ ammonia nitrogen and $78 \%$ of the initial $7.7 \mathrm{mg} / \mathrm{L}$ of $\mathrm{PO}_{4}-\mathrm{P}$ from synthetic wastewater (Aslan and Kapdan, 2006). Many other studies (Chevalier and De la Noüe, 1985; Rai and Mallick, 1992; García et al., 2006) also showed the ability of algae to remove $\mathrm{N}$ and $\mathrm{P}$ simultaneously. While $\mathrm{N}$ removal by microalgae is believed to be the result of assimilation, $\mathrm{P}$ removal by microalgae is still not as well understood and two metabolic processes for $\mathrm{P}$ removal have been still debated:(1) the assimilation of phosphorus for algal growth and (2) luxury $\mathrm{P}$ uptake where $\mathrm{P}$ is stored within the algal biomass as polyphosphates (Powell et al., 2008).

Many parameters can affect nutrient removal by microalgae and these include $\mathrm{pH}$, temperature, nutrient concentrations, and lighting. These variables will differ depending on wastewater and the ability to remove nutrients will vary between algal species and water conditions. In addition, biotic factors can negatively impact algal growth in wastewater. Other microorganisms in wastewater can out-compete the algae for essential nutrients, and pathogenic bacteria or predatory zooplankton will harm the microalgae. The starting population of the microalgae is critical for the growth of the whole population.

\section{Algae for heavy metal removal in wastewater}

Many algae species have the capability of sorbing metals, leading to considerable potential for treating industrial wastewater and leachate containing heavy metals (Li et al., 2009; Suresh et al., 2015). Wastewaters from electroplating, electronics, and metal cleaning are often difficult to treat due to the high amount of heavy metal contamination. Microalgae have been found to be very effective in removing heavy metals due to the high binding affinity of their cell wall (Chong et al., 2000). Heavy metal biosorption by algae is thought to occur in a two-phase process (Kaplan et al., 2013). The first phase is adsorption into extracellular materials (e.g., polysaccharides) and the cell wall (carboxyl, sulfate, and phosphate groups), which is nonmetabolic. The second phase is absorption and accumulation inside the cell. Both phases are effected by many parameters (e.g., $\mathrm{pH}$, temperature, and algae type) and thus studies related to these parameters have been investigated, including the effects of algae type, $\mathrm{pH}$, heavy metal concentration, and algal cell size and shape on heavy metal removal and heavy metal toxicity effects of algae growth (Monteiro et al., 2012; Suresh et al., 2015). The combined use of microalgae for biofuel production and heavy metal removal has also been studied (Richards and Mullins 2013); however, the effects of heavy metal sorption by microalgae on downstream biofuel production processes are still unclear.

\section{Algae for treating EC-polluted wastewaters}

Bioremediation of emerging contaminants (ECs) in wastewater using algae provides a solar power-driven, ecologically comprehensive, and sustainable reclamation strategy. Sorption and biodegradation are known as the main mechanisms for EC removal (Norvill et al., 2016). Sorption of ECs by microalgae is highly specific to the EC structure, species of microalgae, and environmental conditions. A study by Matamoros et al. (2015) found that ECs generally sorbed better or similar to activated sludge biomass than algal biomass. Norvill et al. (2016) summarized the range of EC removal from none to $100 \%$ using various species of microalgae. For biodegradation, it is suggested that microalgae are capable of biodegrading certain EC pollutants heterotrophically or using extracellular enzymes (Norvill et al. 2016). A recent study has compared estrogen removal by live and dead algae (as a control) and found that of the $60-100 \%$ removal, 20-54\% was attributed to biodegradation (Hom-Diaz et al. 2015). Another study advocates biodegradation of antibiotics by microalgae as a detoxification response (Liu et al. 2015).

\section{Bioenergy from Algae: Fuel of the Future}

\section{Pretreatment technologies of algal biomass}

Most microalgae have a resistant cell wall, which hinders the performance of biofuel conversion technologies. Pretreatment techniques are used to breakdown the cell wall and increase bioenergy (i.e., bioethanol) productivity by enhancing the bioaccessibility of intercellular sugars for ethanol fermentation (Choi et al., 2011; Jeon et al., 2013; Hwang et al., 2016). Pretreatment methods can be divided into three categories: physical (thermal and mechanical), chemical, and biological. Physical pretreatments are regarded as the most effective on microalgae cell disruption. They work by breaking down the crystalline structures within cell wall using heat or mechanical agitation (sonication and microwave). Among physical pretreatments, thermal pretreatment is more widely studied, but its effectiveness is highly dependent on the microalgae species. Sonication and microwave pretreatments tend to be less dependent on microalgae species, but are more energy intensive (Passos et al., 2014). Chemical 
Table 3. Pretreatment for Microalgae Ethanol Production

\begin{tabular}{|c|c|c|c|}
\hline Microalgae species & Pretreatment conditions & Results & References \\
\hline Scenedesmus obliquus & Ultrasound (40 KHz; $15 \mathrm{~min})$ & $\begin{array}{l}\text { Pretreatment increased by } 7 \text {-fold } \\
\text { ethanol production }\end{array}$ & Choi et al. (2011) \\
\hline Scenedesmus obliquus & $\begin{array}{l}\text { Ultrasound }(200 \mathrm{~W} ; 30 \mathrm{~s}) / \mathrm{high} \\
\text { pressure }(24,000 \mathrm{rpm} ; 5 \mathrm{~min})\end{array}$ & $\begin{array}{l}\text { Pretreatment did not improve } \\
\text { cell wall disruption }\end{array}$ & Miranda et al. (2012) \\
\hline Rhodosporidium toruloides & Ultrasound ( $800 \mathrm{~W} ; 80 \mathrm{~min}$ ) & $\begin{array}{l}\text { Max. glucose yield }(25 \mathrm{~g} / 100 \mathrm{~g} \\
\text { of biomass) compared to } \\
\text { nonpretreated algae }\end{array}$ & Zhao et al. (2013) \\
\hline Gelidin & Acid and hydrolytic enzyme & $0.40 \mathrm{~g}$ ethanol $/ \mathrm{g}$ of carbohydrate & Kim et al. (2011) \\
\hline Chlorococum humi & Acid & $0.52 \mathrm{~g}$ ethanol $/ \mathrm{g}$ of carbohydrate & $\begin{array}{l}\text { Harun and Danquah } \\
\text { (2011) }\end{array}$ \\
\hline Chlore & & & Harun et al. (2010) \\
\hline Chlamydomonc & Enzymatic & $0.24 \mathrm{ethanol} / \mathrm{g}$ of carbohydrate & Choi et al. (2010) \\
\hline
\end{tabular}

pretreatments use acid or alkali reagents to solubilize polymers within the cell wall, thus increasing the availability of organic compounds for fermentation. When combined with heat, chemical pretreatments are found to be very effective; however, chemical contamination and risk of inhibitor formation limit its use at a commercial scale (Passos et al., 2014). Biological pretreatments, or the use of hydrolytic enzymes to breakdown components of the cell wall, are an effective pretreatment for microalgae, but its research is still limited. One study used an enzymatic mixture composed of $\alpha$-amylase, cellulose, lipase, protease, and xylanase to pretreat Rhizoclonium biomass and found a $20 \%$ improvement in methane production over physical pretreatment (Ehimen et al., 2013). Table 3 presents the bioethanol yields of various microalgae using several pretreatment methods. With the aid of ultrasonication pretreatment, bioethanol yields of algal biomass $(0.258 \mathrm{~g}$ ethanol $/ \mathrm{g}$ biomass $)$ are similar to that of glucose (0.258 g ethanol/g biomass) (Choi et al., 2011; Jeon et al., 2013). This is due to the enhanced bioaccessibility of intercellular sugars after pretreatment. Overall, biofuel production from microalgae can be greatly improved using pretreatment steps; however, it is important to consider the algal species, chemical requirements, and energy demand when designing a bioenergy production process.

\section{Biodiesel production from microalgae}

Microalgae make excellent candidates for large-scale biodiesel production because of their high lipid content (20$50 \%$ [wt/wt]) (Chisti, 2007). Lipid productivity is an important factor for selecting the most adequate algae species for biofuel production. Lipid content in microalgae can reach up to $75 \%$ dry biomass weight; however, high lipid content is typically associated with slow growth and thus low productivities (e.g., Botryococcus braunii). Typical lipid contents of various microalgal species are listed in Table 4. Most microalgae species with high lipid content are not adapted well for growing in wastewater conditions; however, many researchers have isolated microalgae to grow them in wastewater effluents (Zhou et al., 2012; Abou-Shanab et al., 2013). Microalgae isolated from industrial wastewater were evaluated for their growth potential in media supplemented with different organic carbon substrates and resulted in 3-10 times more biomass production and lipid productivity compared to freshwater (Xin et al., 2010; Zhou et al., 2011). To improve lipid production, it is important to understand the lipid biosynthesis pathway and its regulators; however, these pathways have not yet been fully elucidated (Bellou et al., 2014). Most microalgae accumulate lipid under specific stress conditions (e.g., $\mathrm{N}$ depletion or high salinity). Nutritional and environmental factors, $\mathrm{CO}_{2} /$ light intensity, and growth phase are potential cultivation parameters that affect lipid production and quality in microalgae ( $\mathrm{Ji}$ et al., 2014; Van Wagenen et al., 2014). The composition of the lipids or fatty acids is important because it affects the characteristics of biodiesel produced. For example, some algae can produce large amounts of polyunsaturated fatty acids which tend to decrease the stability of biodiesel (Abou-Shanab et al., 2011). In contrast, it is known that algae species that produce high oleic acid (C18:1) are most suitable for the production of high-quality biodiesel because of their reasonable balance of fuel properties, including ignition quality, combustion heat, cold filter plugging point, oxidative stability, viscosity, and lubricity (Or-Rashid et al., 2008).

Biodiesel is a mixture of fatty acid alkyl esters obtained by transesterification (ester exchange reaction) of lipid feedstock (e.g., vegetable oils or animal fats). These lipid feedstock are composed mostly of triglycerides (90-98\%) and small amounts of monoglycerides and diglycerides, and free fatty acids. Residual amounts of phospholipids,

Table 4. Lipid Contents in Various Microalgae STRAins (\% DRY WeIGHT)

\begin{tabular}{lc}
\hline Microalgal species & Lipid content (\%) \\
\hline Ankistrodesmus sp. & $16-21$ \\
Botryococcus sp. & $21-45$ \\
Porphyridium cruentum & $9-14$ \\
Chlorella vulgaris & $28-53$ \\
Chlamydomonas sp. & $16-22$ \\
Dunaliella tertiolecta & $16-71$ \\
Euglena gracilis & $14-20$ \\
Nannochloropsis sp. & $12-53$ \\
Monoraphidium contortum & 22 \\
Scenedesmus obliquus & 17 \\
Synechoccus sp. & 11 \\
Scenedesmus dimorphus & $16-40$ \\
Tribonema minus & 50 \\
\hline
\end{tabular}

Adapted from Borowitzka (2013); Nascimento et al. (2013). 
phosphatides, carotenes, tocopherols, sulfur compounds, and traces of water are also present (Bozbas, 2008). These triglycerides are converted to esters through a multiple-step reaction called transesterification. In the transesterification reaction, esters can have $\mathrm{R} 1, \mathrm{R} 2$, and $\mathrm{R} 3$ as long-chain hydrocarbons. During the reaction, oil or fat (containing triglycerides) undergoes a nucleophilic attack by an incoming alcohol (methanol or ethanol) to give a tetrahedral intermediate, which proceeds to the transesterified product (biodiesel) and a coproduct (glycerol). A base catalyst (i.e., $\mathrm{NaOH}$ ) is typically used to promote formation of biodiesel, although acid catalysts can also be used. Some advanced processes like fixed bed reactors, supercritical reactors, and ultrasonic reactors decrease or completely eliminate the need for chemical catalysts (Warabi et al., 2004). Most common industrial processes use homogeneous alkali catalysts (e.g., $\mathrm{NaOH}$ or $\mathrm{KOH}$ ) in stirred reactors operating in batch mode; however, some improvements for this process are currently being conducted. In particular, microwave-assisted reactors (Azcan and Danisman, 2008; Cravotto et al., 2008), cavitation reactors (Gogate, 2008), and ultrasonic reactors (Kalva et al., 2008) may be able to operate in continuous mode with a reduced reaction time. The alcohol:oil theoretical molar ratio is $3: 1$; however, a molar ratio of $6: 1$ is generally used to complete the reaction. Theoretically, the relationship between the FAME input and biodiesel output is $1: 1$; but in reality, $1 \mathrm{~g}$ of FAME results in $0.84 \mathrm{~g}$ of biodiesel production (El-Shimi et al., 2013).

\section{Bioethanol from algal metabolites}

Bioethanol can be produced from various biomass feedstock, which include easily fermentable starches and sugars associated with first-generation feedstock or low-cost lignocellulosic biomass associated with second-generation feedstock (Chiaramonti, 2007). Lignocellulosic biomass (e.g., grasses, sawdust, and woodchips) are low-cost feedstock, which can be enzymatically hydrolyzed to fermentable sugars for subsequent biofuel production; however, the feasibility of using these materials as a feedstock is often limited by the low yield and high cost of the hydrolysis process (Chen et al., 2003; Wen et al., 2004).

Microalgae are considered to be a biofuel feedstock that is exceedingly rich in carbohydrates and lipids, which can be converted to ethanol by fermentation (Adams et al., 2009; Lü et al., 2011). Although bioethanol fermentation generates a large amount of by-product $\mathrm{CO}_{2}$, this disadvantage can be overcome when bioethanol fermentation is coupled with the cultivation of carbohydrate-rich microalgae (Ho et al., 2011). The $\mathrm{CO}_{2}$ produced from bioethanol fermentation processes can be fully utilized for growing microalgae resulting in carbohydrate-rich microalgal biomass that can be used as feedstock for bioethanol production by fermentation. This integrated process can efficiently achieve the goal of GHG mitigation and reutilization. Moreover, the carbohydrate productivity of microalgae is usually higher compared with lipids since the accumulation of the latter requires intensive stress, while carbohydrate production is readily achieved by photosynthesis through the Calvin cycle. Understanding of fundamentals underlying the carbohydrate metabolism of microalgae is a prerequisite for developing more effective strategies to increase the carbohydrate productivity, which should be optimized by manipulation of the key operating factors (Mooij et al., 2015). In addition, economic and effective saccharification processes should also be developed to enhance the efficiency of biofuel conversion through the microalgae biomass.

\section{Biomethane production by microalgae}

Microalgae are widely used for biomethane production by fermentation because of their high carbohydrate contents. A study by Ward et al. (2014) investigated the anaerobic digestion of Chlorella vulgaris and Scenedesmus, which were cultivated as part of an advanced integrated wastewater pond system. The results showed that biomethane fermentation from these microalgae species requires less energy than biodiesel production, despite lower methane production due to high $\mathrm{N}$ concentrations in wastewater than typical freshwater microalgae.

\section{Microalgal hydrogen production}

Hydrogen production using green algae is possible through the utilization of fermentative metabolism. Several microalgae species (e.g., Scenedesmus sp., Chlorella pyrenoidosa, and Chlamydomonas moewusii) showed their capability of producing molecular hydrogen under anaerobic conditions (Vijayaraghavan et al., 2010). The hydrogen production ability of fresh water algae was also investigated under varying photoperiods (e.g., 2-4 h and alternating light and dark period) and was found to produce $49 \%, 85 \%$, and $88 \%$ of hydrogen content, respectively (Gaffron and Rubin, 1942).

Microalgae convert light energy into chemical energy according to the photosynthetic pathway shown in Figure 2. This process, which takes place in the thylakoid membranes, starts with light absorption by pigment molecules (chlorophylls, phycobilins, and carotenoids) bound to light-harvesting protein complexes associated with two multimembrane protein complexes, Photosystem I (PS I) and Photosystem II (PS II). The unique chlorophyll of PS I and PS II is referred to as P700 and P680 (P means pigment). The absorbed light energy in the pigments is then transferred to the reaction center of PS I and PS II where electrons derived from PS II are passed along the photosynthetic electron-transport chain by plastoquinone (PQ), the cytochrome b6/f complex (Cyb6/f), plastocyanin (PC), PS I, and ferredoxin (FDX). All oxygenic phototrophs (i.e., cyanobacteria and green algae) extract electrons and protons from water and use them to reduce PQ and $\mathrm{NAD}^{+}$ as energy sources for the metabolism. However, they can transiently produce $\mathrm{H}_{2}$ under anaerobic conditions by proton reduction catalyzed by hydrogenase (or nitrogenase) in competition with other intracellular processes. Then, the electrons and protons, which are ultimately produced by water oxidation, are transduced by ferredoxin/NADH to hydrogenase. Thus, the photosynthetically reduced ferredoxin (or NADH) can serve as the physiological electron donor to hydrogenase and links hydrogenase (or nitrogenase) to the electron transport chain (Prince and Kheshgi, 2005).

$\mathrm{H}_{2}$ production rate is usually low in the photosynthetic organisms because oxygen-sensitive hydrogenase is located in the chloroplast where PS II releases $\mathrm{O}_{2}$. There are several natural mechanisms that can be used for lowering the concentration of $\mathrm{O}_{2}$ such as the enhancement of respiration, photochemical reduction of $\mathrm{O}_{2}$ by PS I, and reversible inactivation of $\mathrm{O}_{2}$ evolution in PS II (Kruse et al., 2005). Among 


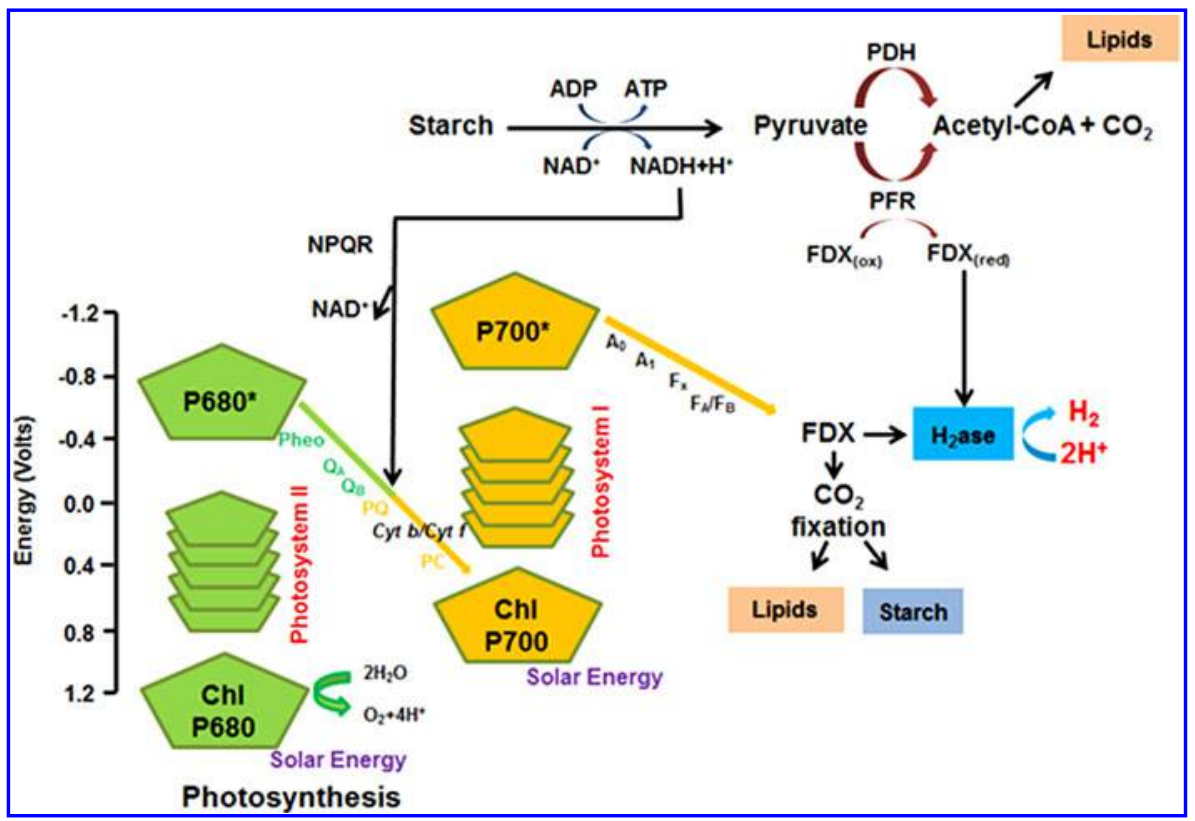

FIG. 2. Photosynthetic and glycolytic pathways in green algae related to biofuel and biohydrogen production. Simplified illustration of the pathways used for lipid, starch, and $\mathrm{H}_{2}$ production in eukaryotic microalgae (Adapted from Beer et al., 2009).

them, sulfur control is commonly used to deplete oxygen in photo systems. Under sulfur-deprived conditions, there is a reversible decline in the rate of oxygenic photosynthesis, which leads to an inactivation of PS II so that cellular respiration draws to "anaerobiosis" and thus initiates $\mathrm{H}_{2}$ evolution by hydrogenase (Melis et al., 2000; Laurinavichene et al., 2008). However, sulfur control is difficult in realworld applications (e.g., wastewater). Recently, Hwang et al. (2014a) observed oxygen production in microalgae right after acetate in anaerobic effluent was consumed beyond a critical level $(<15 \mathrm{mM})$. Therefore, it was proposed that by maintaining acetate concentrations above $15 \mathrm{mM}$, anaerobic conditions can be achieved in real wastewater even without sulfur control. Based on this hypothesis, it is possible to use fermenter effluent as a growth medium and oxygen controller for microalgal hydrogen production. Another study by Hwang et al. (2014b) demonstrated the expression and the specific activity of hydrogenase by Chlorella vulgaris under atmospheric oxygen levels. This result shows that eukaryotic microalgae have an oxygen-tolerant [FeFe] hydrogenase, and further research could identify the gene of the oxygen-tolerant hydrogenase, which could provide an opportunity to develop an artificial oxygen-tolerant hydrogenase technology.

\section{Biohydrogen in fuel cells and biorefineries}

Microbial fuel cells (MFCs) are bioelectrochemical systems that utilize exoelectrogenic bacteria to produce electricity using wastewater. A study by Rosenbaum et al. (2010) proposed the use of photosynthetic microorganisms as biocatalysts for oxidation-reduction reactions that occur in the anode and cathode compartments of an MFC. The systems are known commonly known as photo MFCs (Photo-MFCs) and are capable of using the cost-free solar radiation to generate energy. The advantage of photo-MFCs lies with the possibility of the biodegradation of wastewater by bacteria in the anode and $\mathrm{CO}_{2}, \mathrm{~N}$, and $\mathrm{P}$ fixation by microalgae in the cathode concomitant with the production of bioelectricity.
A microbial electrolysis cell (MEC) is an emerging technology that utilizes biodegradable wastewater for microbial hydrogen production by applying an electric current. Like MFCs, MECs are bioelectrochemical systems that utilize exoelectrogenic bacteria to produce electricity; however, instead of using oxygen as an electron acceptor, the cathode is stored in an anaerobic environment where hydrogen can be generated. Microalgae, however, may be poor candidates for MECs due to their oxygen production (Logan et al., 2006; Logan, 2008).

\section{Harvesting, Separation, and Dewatering of Microalgae Biomass}

Algal biomass is considered valuable for biofuel production; however, the growth of algae in suspension (0.02$0.06 \%$ dry solids) poses considerable challenges in achieving a cost-effective energy balance in algal process operations (Uduman et al., 2010). By nature, microalgae are difficult to remove from solution. Microalgae are smaller than $30 \mu \mathrm{m}$ and have similar densities to water (Golueke and Oswald, 1965; Pahl et al., 2013). Healthy algae have negative surface charges along their cell walls resulting in a stable suspension (Vandamme et al., 2011). Cost-effective harvesting of microalgae is considered to be the most problematic area of algal biofuel production and limits the commercial use of algae (Uduman et al., 2010; Pahl et al., 2013). There are many microalgae harvesting and dewatering techniques, each with tradeoffs between efficiency and economic feasibility. These techniques commonly include sedimentation, flocculation, flotation, filtration, centrifugation, and a combination of these methods. This section attempts to provide an overview of microalgal harvesting techniques and provide advantages and disadvantages for each method.

\section{Sedimentation}

Sedimentation is a process where gravitational forces cause liquid or solid particles to separate from a liquid of a 
different density. Different microalgae have different settling velocities; for common spherical microalgae (Chlorella), settling velocity is calculated at $0.1 \mathrm{~m} /$ day (Edzwald, 1993). Experimental studies found higher settling rates, but this is not typical (Milledge and Heaven, 2013). Settling rates have been shown to differ with light intensity, nutrient deficiency, and cell age (Milledge and Heaven, 2013). Sedimentation is not typically used for harvesting microalgae (Uduman et al., 2010). Cell recovery (60-65\%) and solid concentrations (0.1-1.5\% dry biomass) are low for this method. Energy consumption; however, presents a strong argument for the use of sedimentation. A review of harvesting microalgae written by Milledge and Heaven (2013) recommends the method as a preconcentration step for use with other harvesting techniques (Milledge and Heaven, 2013).

\section{Flocculation}

Flocculation is a process where algae cells group together in flocs either spontaneously or due to the addition of a flocculant. Increasing the size of particles through flocculation can increase the rate of settling or flotation, which makes flocculation a popular pretreatment step to other harvesting methods (Brennan and Owende, 2010). Lime and multivalent metal salts (e.g., ferric chloride, ferric sulfate, and aluminum chloride) are commonly used in wastewater treatment to remove suspended solids. These salts have also been proven effective for removing microalgae from wastewater (Papazi et al., 2010). These inorganic flocculants; however, can have negative effects on microalgal viability and change the growth media which prevent reuse (Milledge and Heaven, 2013). Cationic polyelectrolytes are very effective for recovering microalgae. In addition to neutralizing the surface charge on cells, the polymer can physically link one or more cells through a process called bridging (Grima et al., 2003). Research suggests that cationic polyelectrolytes can produce up to 35 times more biomass than metal salts with lower doses (25 mg/L) (Granados et al., 2012). Nonionic polymers are also effective in recovering microalgae at low concentrations $(0.5-1 \mathrm{mg} / \mathrm{L})$ (Harith et al., 2009). Rather than adding chemicals for flocculation, electrocoagulationflocculation can induce flocculation by producing the coagulant through electrolytic oxidation of an anode, typically iron or aluminum. Microorganisms living in consortium with microalgae can prompt flocculation and produce bioflocculants. The bacterium Paenibacillus sp. AM49 has been shown to produce a bioflocculant that is effective for harvesting Chlorella vulgaris (Oh et al., 2001). There is a wide range of flocculants available for algae harvesting; however, no single flocculation method is suitable for all microalgae species and environments. One apparent advantage over other harvesting methods is the low energy consumption.

\section{Flotation}

Flotation is a process that uses air bubbles to float microalgae to the surface. Flotation processes are categorized by the method of bubble production. Dissolved air flotation (DAF) is a process that involves the release of pressurized water saturated with air into a flotation tank at atmospheric pressure, which creates bubbles ranging from 10 to $100 \mu \mathrm{m}$. This is the most preferred method of wastewater treatment lagoons that harvest microalgal biomass. A study by Edzwald
(1993), found that DAF in combination with chemical flocculation is more effective than sedimentation. A disadvantage to using DAF is the high energy required to pressurize the water. Dispersed air flotation, also called foam or froth flotation, is a process where algae are floated in a reactor with a high-speed mechanical agitator through which a constant stream of air is passed. The resulting bubbles $(\sim 1 \mathrm{~mm}$ in diameter) rise to the surface, carrying the algae cells, and accumulate as foam. This process is highly dependent on hydrophobic interactions and its effectiveness can be dependent on microalgal species and growth media (Garg et al., 2012).

Flotation, in combination with flocculation, is an effective method for harvesting microalgae. Unlike sedimentation, the process is quick and can remove $95 \%$ of algae in less than 20 min (Sharma et al., 2013). The process, however, can have high operational costs due to the small bubbles required. A review of flotation concluded that the costs of flotation can be equal to or greater than centrifugation when calculating for flocculants, surfactant, and energy costs (Benemann and Oswald, 1996).

\section{Filtration}

Filtration is a highly efficient method for harvesting algae and has been widely studied. When compared to centrifugation, filtration is considered a simpler and lower cost alternative (Sharma et al., 2013). However, membrane filtration can be costly for large-scale processes due to membrane replacement, fouling, and pumping (Uduman et al., 2010; Milledge and Heaven, 2013). Typically, microfiltration (0.1-10 $\mu \mathrm{m}$ pore size) is most suitable for harvesting algae, although macrofiltration can be used for large or flocculated cells (Milledge and Heaven, 2013). Rotary vacuum filters and belt filters are widely used in the wastewater industry and have been studied for use in harvesting microalgae. A study by Mohn (1988) showed that large microalgae like Coelastrum can be filtered to $18 \%$ dry weight using a rotary vacuum filter, but smaller microalgae cannot be effectively harvested using belt or rotary vacuum filters (Mohn, 1988). Tangential flow filtration seems promising and has been shown to help with fouling problems, especially when combined with flocculation; however, the process can still be energy intensive (Danquah et al., 2009). Recently, forward osmosis (FO) has emerged as an effective separation process for algae biofuel production. The method consumes lower energy compared to other filtration techniques by using osmotic pressure created by an ionic strength gradient to drive the process. The NASA OMEGA project and other studies have suggested FO to be a cost-saving step in dewatering freshwater microalgae (Buckwalter et al., 2013). Disadvantages of FO include low flux rates $\left(4 \mathrm{~L} / \mathrm{h} \cdot \mathrm{m}^{-2}\right)$ and the limitation to freshwater cultivation.

\section{Centrifugation}

Centrifugation can rapidly and efficiently harvest algae and is considered one of the most practical harvesting methods (Sharma et al., 2013). Many sizes and types of centrifuges are currently being used on an industrial scale. A disc stack centrifuge is among the most common used in industry (Uduman et al., 2010). Other centrifuge designs include the decanter, hydrocyclone, and spiral plate centrifuges (Milledge 
and Heaven, 2013). Spiral plate centrifuges are now being considered one of the top designs for algae harvesting.

\section{Drying}

After harvesting, drying is needed for conventional methods of energy extraction ( $>85 \%$ DW). Drying can be energy intensive due to the high enthalpy of water; therefore, it is preferable to use other dewatering methods (mentioned above) before drying (Sharma et al., 2013). Common methods for drying microalgae are spray drying, drum drying, freeze drying, and sun drying. Spray and freeze drying are considered too costly for biofuel. Solar drying is the most economical, but requires large areas of land.

\section{Wet harvesting}

Microalgae in suspension ( $\sim 30 \% \mathrm{DW})$ can also be harvested using wet extraction techniques. Currently, direct wet extraction of microalgae is not used on a large scale. However, several wet extraction methods show promising results at the laboratory scale. Origin Oil has developed a process called Quantum Fracturing where pulsed electromagnetic fields fracture the algal cells and the resulting lipids float to the surface, while the remaining biomass settles out. Supercritical $\mathrm{CO}_{2}$ has also been proven to extract lipids. Xu et al. (2011) evaluated the energy balance of dry oil extraction (dried algae) and wet oil extraction (in water phase) and found that, while both consumed a significant amount of energy, the dry route could be significantly improved by utilizing waste heat from a nearby power plant. The study found that the potential fossil energy ratio could reach 2.38 and 1.82 for the dry and wet route, respectively. Similarly, hydrothermal or thermochemical liquefaction of algae biomass has grain attention as a biofuel production method because of its ability to produce biofuel without the need for feedstock drying (Shuping et al., 2010; Huang et al., 2011); however, high energy is needed to reach the conditions needed for the process (e.g., critical point of water is $647.3 \mathrm{~K}$, $22.1 \mathrm{MPa}$ ) (Yuan et al., 2011).

\section{Life Cycle Assessment and Economics of Wastewater-Based Algal Biofuels}

\section{Life cycle assessment}

Life cycle assessment (LCA) is a systems-based process of assessing and calculating the human health, energy, and environmental burdens of those commodities from "cradle to grave" and provides a method to (1) collect and manage materials and energy information for a life cycle and (2) assess the potential energy and environmental impacts of materials and energy flows. LCA has become an extremely useful and popular option to assess the environmental impacts of emerging technologies (Kim and Dale, 2005; Gnansounou et al., 2009; Cherubini and Strømman, 2011; Rodríguez et al., 2011; Lee et al., 2015).

To better assess the costs and benefits of commercializing algal biofuels, one would need to evaluate their life cycle sustainability. Due to the difficulty of assessing sustainability using independent metrics, LCA is a favorable method to systemically integrate these metrics to ultimately determine the energy and environmental impacts of algal biofuels. Mu et al. (2014) surveyed the environmental impacts of wastewater-based algal biofuels as it is proposed to be a more commercial sustainable option. Four nutrient sources were examined: municipal wastewater influent to the activated sludge process, centrate from the sludge drying process, swine manure, and freshwater with synthetic fertilizers. Four algae biofuel conversion technologies were considered: microwave pyrolysis, direct combustion, hydrothermal liquefaction (HTL), and lipid extraction-altogether creating 16 unique production pathways. Impacts evaluated were fossil fuel use, GHG emissions, eutrophication, and water use. Overall, the results showed that wastewater-based algal biofuels had lower environmental impacts than freshwater-based fuels, depending on the characteristics of the wastewater and the conversion technologies. Although both did not generally perform better than petroleum diesel, the centrate cultivation with the wet lipid pathway and the centrate cultivation with the combustion pathway had lower impacts across all impact categories compared to petroleum diesel. Yang et al. (2011) specifically focused on the life cycle of water and nutrient usage of biofuels from microalgae. They estimated that in the case of algal biodiesel from freshwater, $3,726 \mathrm{~kg}$ of water is needed to produce $1 \mathrm{~kg}$ of biodiesel, if no water is recycled. Recycling water can significantly reduce life cycle consumption of $\mathrm{N}, \mathrm{P}$, potassium, magnesium, and sulfur. Furthermore, wastewaterbased biofuels can reduce nitrogen impacts by $94 \%$ and does not require potassium, magnesium, and sulfur (Yang et al., 2011).

Most LCA studies on algal biofuels have focused on quantifying the global warming potential, net energy ratio, and the energy return on investment. There have been several LCA studies of microalgae biofuels (Batan et al., 2010; Brentner et al., 2011; Campbell et al., 2011; Frank et al., 2011, 2013; Shirvani et al., 2011; Vasudevan et al., 2012; Grierson et al., 2013; Liu et al., 2013; Passell et al., 2013; Sills et al., 2013; Adesanya et al., 2014; Azadi et al., 2014; Collet et al., 2014; Handler et al., 2014; Ponnusamy et al., 2014; Quinn et al., 2014; Soh et al., 2014; Woertz et al., 2014). As with LCAs of emerging technologies and energy systems, there is a large variability of results, mostly driven by differences in productivity rates and technology pathways. Furthermore, methodological differences, such as system boundaries, core LCA assumptions, coproduct allocation methods, energy mixes, and inventory data can all significantly contribute to the variability of LCA results. The majority of these studies have focused on traditional lipid extraction systems, while others considered utilized thermochemical conversion, secretion, or supercritical water bio-oil recovery technologies (Quinn and Davis, 2015). A compilation of these studies reported GHG emissions ranging from -95.7 to $534 \mathrm{~g} / \mathrm{CO}_{2}$-eq/MJ, all with a well-to-pump system boundary (Quinn and Davis 2015). Studies surveying thermochemical conversion, specifically HTL, showed GHG emissions as low as $-44 \mathrm{~g} / \mathrm{CO}_{2^{-}} \mathrm{eq} / \mathrm{MJ}$ and as high as $33 \mathrm{~g} / \mathrm{CO}_{2^{-}}$ eq/MJ (Frank et al., 2013; Liu et al., 2013). The lowest result among all studies was reported by Ponnusamy et al. (2014), which considered a supercritical water technology for lipid recovery. Most LCAs of biofuels exclude infrastructure from their system boundaries. However, both Adesanya et al. (2014) and Canter et al. (2014) studied the integration of facility construction-related impacts, with the latter focusing solely on infrastructure-associated emissions. Results from these studies 
showed that infrastructure can have significant impacts on GHG emissions depending on yields.

A common theme behind almost all LCA studies is the dominance of energy across all impact categories. This may not be an issue at small scales, but with the goal of achieving large-scale production, energy-related impacts can determine the success or failure of algal biofuels of becoming sustainable. However, there is still work needed in harmonizing LCA results of algal biofuels. Due to differences in production pathways, assumptions, parameters, and data quality, the consequence is a large variability of results, which makes it difficult to compare results, given changing geographical or technological conditions (Chiaramonti et al., 2015). Despite these challenges, LCA is an effective decision-making tool for developing solutions toward sustainable algal fuels. Overall, LCA results indicate that algal biofuels, particularly those utilizing wastewater, have a large potential to introduce environmental benefits, especially given that biofuel sustainability is a critical issue.

\section{Economics}

The economic feasibility of commercial algal biofuel production is dependent on the large-scale productivity potential of microalgae. The biggest barrier to commercializing algal biofuels is the difficulty in replicating the productivity potential for large-scale production. A significant advantage of microalgae is the potential for high production rates relative to terrestrial feedstock. However, achieving this at a large scale has proven to be challenging (Quinn et al., 2012). Despite this difficulty, several studies have performed technoeconomic feasibility studies to understand the economic feasibility of various production pathways. These studies have typically coupled engineering-based process modeling with economic analysis to determine selling prices on a pergallon basis. A review of literature performed by Quinn and Davis (2015) shows a low cost for production at $\$ 1.65 /$ gallon and a high cost of $\$ 33.16 /$ gallon. This variability is caused by differences in system boundaries, production pathways, and temporal coverages. Sun et al. (2011) performed a harmonization of results, resulting in a narrower range of $\$ 11.68$ $\$ 14.31 /$ gallon. Differences between growth architectures contribute to the economic feasibility as well. Open raceway ponds (ORP) and PBRs are two major pathways. Studies that have compared the costs between the two have concluded that ORP is more economically feasible than PBR by more than a factor of 2 (Davis et al., 2011; Richardson et al., 2012). In addition to GHG emissions, Campbell et al. (2011) also compared costs of algal biodiesel production to canola and ULS diesel. The costs of feedstock production, transformation and distribution, capital, and excise were all considered, for both a low production rate of $15 \mathrm{~g} / \mathrm{m}^{2} /$ day and high rate of $30 \mathrm{~g} / \mathrm{m}^{2} /$ day. The results showed that algal biodiesel cost ranges from 2.2 to 4.8 cents $/ \mathrm{tkm}$ (tonne- $\mathrm{km}$ ). The lower cost is by delivery of flue gas, while the higher cost is from $\mathrm{CO}_{2}$ delivery by truck. Canola and ULS diesel have costs of 4.2 and 3.8 cents/tkm, respectively.

\section{Conclusions and Recommendations}

Despite a lengthy list of benefits offered by algae-based biofuel, full-scale implementation of algae as a bioenergy source has been prohibitively expensive till date, especially when cultivated using artificial media (Lundquist et al., 2010). Large energy inputs are required for algae cultivation and harvesting; thus integration of algae production with industrial processes like wastewater treatment and $\mathrm{CO}_{2}$ utilization from power plants are needed to distribute economic costs (Fig. 1). Likewise, all valuable components of microalgae need to be utilized. Lipids and carbohydrates can be used for biodiesel and bioethanol, respectively, and the remaining pigments, proteins, and vitamins can also be refined into valuable products.

To become a mature technology, several research questions still need to be addressed (Sivakumar et al., 2012). (1) More experience is required with the practicality and utility of separating protein, lipid, and carbohydrate fractions from one another; (2) novel and more cost-effective harvesting technologies need to be developed, which show a high separation yield; (3) $\mathrm{CO}_{2}$ capture from regional power plants need to be considered or recycling $\mathrm{CO}_{2}$ needs to be used in the PBRs; and (4) pathogen or EC removal using algal technology needs to be developed for integrated algal culture system. Nevertheless, advancements in microbiology, chemistry, and environmental engineering, combined with additional funding and research, should allow for rapid commercialization of this new biofuel and wastewater treatment technology. Although there is much more to be discovered, current literature supports algae as a promising biofuel source and effective wastewater treatment strategy.

\section{Acknowledgments}

This work was supported by the U.S. Environmental Protection Agency (EPA) (SU836132) and by the National Aeronautics and Space Administration (NASA) (NNX15AN65A and NNX15AI10H).

\section{Author Disclosure Statement}

No competing financial interests exist.

\section{References}

Abou-Shanab, R.A.I., Hwang, J. H., Cho, Y., Min, B., and Jeon, B.-H. (2011). Characterization of microalgal species isolated from fresh water bodies as a potential source for biodiesel production. Appl. Energy 88, 3300.

Abou-Shanab, R.A.I., Ji, M.K., Kim, H.C., Paeng, K.J., and Jeon, B.H. (2013). Microalgal species growing on piggery wastewater as a valuable candidate for nutrient removal and biodiesel production. J. Environ. Manage. 115, 257.

Adams, J.M., Gallagher, J.A., and Donnison, I.S. (2009). Fermentation study on Saccharina latissima for bioethanol production considering variable pre-treatments. J. Appl. Phycol. $21,569$.

Adesanya, V.O., Cadena, E., Scott, S.A., and Smith, A.G. (2014). Life cycle assessment on microalgal biodiesel production using a hybrid cultivation system. Bioresour. Technol. $163,343$.

Aslan, S., and Kapdan, I.K. (2006). Batch kinetics of nitrogen and phosphorus removal from synthetic wastewater by algae. Ecol. Eng. 28, 64.

Azadi, P., Brownbridge, G., Mosbach, S., Smallbone, A., Bhave, A., Inderwildi, O., and Kraft, M. (2014). The carbon footprint and non-renewable energy demand of algae-derived biodiesel. Appl. Energy 113, 1632. 
Azcan, N., and Danisman, A. (2008). Microwave assisted transesterification of rapeseed oil. Fuel 87, 1781.

Batan, L., Quinn, J., Willson, B., and Bradley, T. (2010). Net energy and greenhouse gas emission evaluation of biodiesel derived from microalgae. Environ. Sci. Technol. 44, 7975.

Beer, L.L., Boyd, E.S., Peters, J.W., and Posewitz, M.C. (2009). Engineering algae for biohydrogen and biofuel production. Curr. Opin. Biotechnol. 20, 264.

Bellou, S., Baeshen, M.N., Elazzazy, A.M., Aggeli, D., Sayegh, F., and Aggelis, G. (2014). Microalgal lipids biochemistry and biotechnological perspectives. Biotechnol. Adv. 32, 1476

Borowitzka, M.A. (2013). High-value products from microalgaetheir development and commercialisation. J. Appl. Phycol. 25, 743 .

Bozbas, K. (2008). Biodiesel as an alternative motor fuel: Production and policies in the European Union. Renew. Sust. Energy Rev. 12, 542.

Brennan, L., and Owende, P. (2010). Biofuels from microalgaea review of technologies for production, processing, and extractions of biofuels and co-products. Renew. Sust. Energy Rev. 14, 557.

Brentner, L.B., Eckelman, M.J., and Zimmerman, J.B. (2011). Combinatorial life cycle assessment to inform process design of industrial production of algal biodiesel. Environ. Sci. Technol. 45, 7060.

Buckwalter, P., Embaye, T., Gormly, S., and Trent, J.D. (2013). Dewatering microalgae by forward osmosis. Desalination 312, 19.

Campbell, P.K., Beer, T., and Batten, D. (2011). Life cycle assessment of biodiesel production from microalgae in ponds. Bioresour. Technol. 102, 50.

Canter, C.E., Davis, R., Urgun-Demirtas, M., and Frank, E.D. (2014). Infrastructure associated emissions for renewable diesel production from microalgae. Algal Res. 5, 195.

Chen, S., Liao, W., Liu, C., Kincaid, R., and Harrison, J. (2003). Use of animal manure as feedstock for bio-products. In Animal, Agricultural and Food Processing Wastes-IX. American Society of Agricultural and Biological Engineers, p. 50, St. Joseph, MI, USA.

Cherubini, F., Bird, N.D., Cowie, A., Jungmeier, G., Schlamadinger, B., and Woess-Gallasch, S. (2009). Energy-and greenhouse gas-based LCA of biofuel and bioenergy systems: Key issues, ranges and recommendations. Resour. Conserv. Recy. 53, 434.

Chevalier, P., and De la Noüe, J. (1985). Efficiency of immobilized hyperconcentrated algae for ammonium and orthophosphate removal from wastewaters. Biotechnol. Lett. 7, 395.

Chiaramonti, D. (2007). Bioethanol: role and production technologies. In Improvement of crop plants for industrial end uses (pp. 209). Springer, Netherlands.

Chiaramonti, D., Maniatis, K., Tredici, M., Verdelho, V., and Yan, J. (2015). Life cycle assessment of algae biofuels: Needs and challenges. Appl. Energy 154, 1049.

Chisti, Y. (2007). Biodiesel from microalgae. Biotechnol. Adv. 25, 294.

Choi, J.-A., Hwang, J.H., Dempsey, B.A., Abou-Shanab, R.A.I., Min, B., Song, H., Lee, D.S., Kim, J.R., Cho, Y., Hong, S., Hong. S., and Jeon, B.H. (2011). Enhancement of fermentative bioenergy (ethanol/hydrogen) production using ultrasonication of Scenedesmus obliquus YSW15 cultivated in swine wastewater effluent. Energy Environ. Sci. 4, 3513.

Choi, S.P., Nguyen, M.T., and Sim, S.J. (2010). Enzymatic pretreatment of Chlamydomonas reinhardtii biomass for ethanol production. Bioresour. Technol. 101, 5330.
Chong, A., Wong, Y., and Tam, N. (2000). Performance of different microalgal species in removing nickel and zinc from industrial wastewater. Chemosphere 41, 251.

Christenson, L.B., and Sims, R.C. (2012). Rotating algal biofilm reactor and spool harvester for wastewater treatment with biofuels by-products. Biotechnol. Bioeng. 109, 1674.

Collet, P., Lardon, L., Hélias, A., Bricout, S., Lombaert-Valot, I., Perrier, B., Lépine, O., Steyer, J.P., and Bernard, O. (2014). Biodiesel from microalgae-life cycle assessment and recommendations for potential improvements. Renew. Energy $71,525$.

Craggs, R., Park, J., Sutherland, D., and Heubeck, S. (2015). Economic construction and operation of hectare-scale wastewater treatment enhanced pond systems. J. Appl. Phycol. 27, 1913.

Cravotto, G., Boffa, L., Mantegna, S., Perego, P., Avogadro, M., and Cintas, P. (2008). Improved extraction of vegetable oils under high-intensity ultrasound and/or microwaves. $\underline{U l-}$ trason. Sonochem. 15, 898.

Danquah, M.K., Ang, L., Uduman, N., Moheimani, N., and Forde, G.M. (2009). Dewatering of microalgal culture for biodiesel production: Exploring polymer flocculation and tangential flow filtration. J. Chem. Technol. Biotechnol. 84, 1078.

Davis, R., Aden, A., and Pienkos, P.T. (2011). Technoeconomic analysis of autotrophic microalgae for fuel production. Appl. Energy 88, 3524.

Dismukes, G.C., Carrieri, D., Bennette, N., Ananyev, G.M., and Posewitz, M.C. (2008). Aquatic phototrophs: Efficient alternatives to land-based crops for biofuels. Curr. Opin. Biotechnol. 19, 235.

Dragone, G., Fernandes, B., Vicente, A.A., and Teixeira, J.A. (2010). Third generation biofuels from microalgae. In A. Mendez-Vilas, Ed., Current Research, Technology and Education Topics in Applied Microbiology and Microbial Biotechnology (Microbiology Book Series 2). Badajoz: Formatex, p. 1355.

Edzwald, J. (1993). Algae, bubbles, coagulants, and dissolved air flotation. Water Sci. Technol. 27, 67.

Ehimen, E., Holm-Nielsen, J., Poulsen, J., and Boelsmand, J. (2013). Influence of different pre-treatment routes on the anaerobic digestion of a filamentous algae. Renew. Energy $50,476$.

El-Shimi, H.I., Attia, N.K., El-Sheltawy, S.T., and El-Diwani, G.I. (2013). Biodiesel production from Spirulina-Platensis microalgae by in-situ transesterification process. J. Sustain. Bioenerg. Syst 3, 224.

Food and Agriculture Organization of the United Nations (FAO). (2008). The State of Food and Agriculture 2008. Rome, Italy. FAO. (2008). The State of Food and Agriculture 2008. New York: Food and Agriculture Organization.

Frank, E., Han, J., Palou-Rivera, I., Elgowainy, A., and Wang, M. (2011). Life-Cycle Analysis of Algal Lipid Fuels with the GREET Model. Oak Ridge: Center for Transportation Research, Energy Systems Division, Argonne National Laboratory, p. 11.

Frank, E.D., Elgowainy, A., Han, J., and Wang, Z. (2013). Life cycle comparison of hydrothermal liquefaction and lipid extraction pathways to renewable diesel from algae. Mitig. Adapt. Strat. GL. 18, 137.

Gaffron, H. and Rubin, J. (1942). Fermentation and photochemical products of hydrogen in algae. J. Gen. Physiol. 26, 219.

García, J., Green, B., Lundquist, T., Mujeriego, R., HernándezMariné, M., and Oswald, W. (2006). Long term diurnal variations 
in contaminant removal in high rate ponds treating urban wastewater. Bioresour. Technol. 97, 1709.

Garg, S., Li, Y., Wang, L., and Schenk, P.M. (2012). Flotation of marine microalgae: Effect of algal hydrophobicity. Bioresour. Technol. 121, 471.

Ghirardi, M.L., Zhang, L., Lee, J.W., Flynn, T., Seibert, M., Greenbaum, E., and Melis, A. (2000). Microalgae: A green source of renewable $\mathrm{H}_{2}$. Trends Biotechnol. 18, 506.

Gnansounou, E., Dauriat, A., Villegas, J., and Panichelli, L. (2009). Life cycle assessment of biofuels: Energy and greenhouse gas balances. Bioresour. Technol. 100, 4919.

Gogate, P.R. (2008). Cavitational reactors for process intensification of chemical processing applications: A critical review. Chem. Eng. Process. 47, 515.

Golueke, C.G., and Oswald, W.J. (1965). Harvesting and processing sewage-grown planktonic algae. J. Water. Pollut. Con. F. 37, 471.

Granados, M., Acién, F., Gomez, C., Fernandez-Sevilla, J., and Grima, E.M. (2012). Evaluation of flocculants for the recovery of freshwater microalgae. Bioresour. Technol. 118 , 102.

Grierson, S., Strezov, V., and Bengtsson, J. (2013). Life cycle assessment of a microalgae biomass cultivation, bio-oil extraction and pyrolysis processing regime. Algal Res. 2, 299.

Grima, E.M., Belarbi, E.H., Fernández, F.A., Medina, A.R., and Chisti, Y. (2003). Recovery of microalgal biomass and metabolites: Process options and economics. Biotechnol. Adv. 20, 491.

Handler, R.M., Shonnard, D.R., Kalnes, T.N., and Lupton, F.S. (2014). Life cycle assessment of algal biofuels: Influence of feedstock cultivation systems and conversion platforms. $\underline{\text { Algal }}$ Res. 4, 105.

Harith, Z.T., Yusoff, F.M., Mohamed, M.S., Shariff, M., Din, M., and Ariff, A.B. (2009). Effect of different flocculants on the flocculation performance of flocculation performance of microalgae, Chaetoceros calcitrans, cells. Afr. J. Biotechnol. 8, 5971 .

Harun, R., and Danquah, M.K. (2011). Influence of acid pretreatment on microalgal biomass for bioethanol production. Process Biochem. 46, 304.

Harun, R., Jason, W., Cherrington, T., and Danquah, M.K. (2011). Exploring alkaline pre-treatment of microalgal biomass for bioethanol production. Appl. Energy 88, 3464.

Hirano, A., Ueda, R., Hirayama, S., and Ogushi, Y. (1997). $\mathrm{CO}_{2}$ fixation and ethanol production with microalgal photosynthesis and intracellular anaerobic fermentation. Energy 22,137

Ho, S.-H., Chen, C.-Y., Lee, D.-.J., and Chang, J.-S. (2011). Perspectives on microalgal $\mathrm{CO}_{2}$-emission mitigation systems-a review. Biotechnol. Adv. 29, 189.

Hom-Diaz, A., Llorca, M., Rodríguez-Mozaz, S., Vicent, T., Barceló, D., and Blánquez, P. (2015). Microalgae cultivation on wastewater digestate: $\beta$-estradiol and $17 \alpha$-ethynylestradiol degradation and transformation products identification. $\underline{J}$. Environ. Manage. 155, 106.

Huang, D., Dhawan, T., Young, S., Yong, W.H., Boros, L.G., and Heaney, A.P. (2011). Fructose impairs glucose-induced hepatic triglyceride synthesis. Lipids Health Dis. 10, 1.

Huang, H., Yuan, X., Zeng, G., Wang, J., Li, H., Zhou, C., Pei, X., You, Q., and Chen, L. (2011). Thermochemical liquefaction characteristics of microalgae in sub- and supercritical ethanol. Fuel Process. Technol. 92, 147.

Hwang, J.H., Kabra, A.N., Ji, M.K., Choi, J., El-Dalatony, M.M., and Jeon, B.H. (2016). Enhancement of continuous fermentative bioethanol production using combined treatment of mixed microalgal biomass. Algal Res. 17, 14.

Hwang, J.H., Kabra, A.N., Kim, J.R., and Jeon, B.-H. (2014a). Photoheterotrophic microalgal hydrogen production using acetate-and butyrate-rich wastewater effluent. Energy 78, 887.

Hwang, J.H., Kim, H.C., Choi, J.-A., Abou-Shanab, R.A.I., Dempsey, B.A., Regan, J.M., Kim, J.R., Song, H., Nam, I.-H., Kim, S.N., Lee, W., Park, D., Kim, Y., Cho, J., Ji, M.K., Jung, W., and Jeon B.H. (2014b). Photoautotrophic hydrogen production by eukaryotic microalgae under aerobic conditions. Nat. Commun. 5, 3234.

Illman, A., Scragg, A., and Shales, S. (2000). Increase in Chlorella strains calorific values when grown in low nitrogen medium. Enzyme Microb. Technol. 27, 631.

International Energy Agency (IEA). (2007a). World Energy Outlook 2007. Paris: International Energy Agency.

International Energy Agency (IEA). (2007b). IEA Energy Technology Essentials-Biofuel Production, Paris, France.

Jeon, B.H., Choi, J.-A., Kim, H.-C., Hwang, J.H., Abou-Shanab, R.A.I., Dempsey, B.A., Regan, J.M., and Kim, J.R. (2013). Ultrasonic disintegration of microalgal biomass and consequent improvement of bioaccessibility/bioavailability in microbial fermentation. Biotechnol. Biofuels 6, 1.

Ji, M.K., Abou-Shanab, R.A.I., Hwang. J.H., Timmes, T.C., Kim, H.-C., Oh, Y.-K., and Jeon, B-H. (2013). Removal of nitrogen and phosphorus from piggery wastewater effluent using the green microalga Scenedesmus obliquus. J. Environ. Eng. 139, 1198.

Kaewpintong, K. (2004). Cultivation of Haematococcus pluvialis in airlift bioreactor. Bioresour. Techonl. 98, 288.

Kaplan, D., Richmond, A., and Hu, Q. (2013). Absorption and adsorption of heavy metals by microalgae. In: Richmond, A., and $\mathrm{Hu}, \mathrm{Q}$, Ed. Handbook of Microalgal Culture: Applied Phycology and Biotechnology, second ed. Wiley-Blackwell, p. 602.

Kesaano, M., and Sims, R.C. (2014). Algal biofilm based technology for wastewater treatment. Algal Res. 5, 231.

Kim, H.C., Fthenakis, V., Choi, J.K., and Turney, D.E. (2012). Life cycle greenhouse gas emissions of thin-film photovoltaic electricity generation. J. Ind. Ecol. 16, S110.

Kim, H.W., Park, S. and Rittmann, B.E. (2015). Multicomponent kinetic for the growth of the cyanobacterium Synechocystics sp. PCC6803. Environ. Eng. Res. 20, 347.

Kim, H.W., Vannela, R., Zhou, C., and Rittmann, B.E. (2011). Nutrient acquisition and limitation for the photoautotrophic growth of Synechocystis sp. PCC6803 as a renewable biomass source. Biotechnol. Bioeng. 108, 277.

Kim, J., Yoo G., Lee, H., Lim J., Kim, K., Kim, C.W., Park, M.S., and Yang, J.-W. (2013). Methods of downstream processing for the production of biodiesel from microalgae. Biotechnol. Adv. 31, 862.

Kim, N.-J., Li, H., Jung, K., Chang, H.N., and Lee, P.C. (2011). Ethanol production from marine algal hydrolysates using Escherichia coli KO11. Bioresour. Technol. 102, 7466.

Kim, S., and Dale, B.E. (2005). Life cycle assessment of various cropping systems utilized for producing biofuels: Bioethanol and biodiesel. Biomass Bioenergy 29, 426.

Kim, Y.S., Chae, S.W., Park, D.H., and Sunwoo, C. (2010). Pretreatment of Gelidium amansii for the production of bioethanol. Bull. Korean Chem. Soc. 131, 511.

Kruse, O., Rupprecht, J., Bader, K.-P., Thomas-Hall, S., Schenk, P.M., Finazzi, G., and Hankamer, B. (2005). Improved photobiological $\mathrm{H}_{2}$ production in engineered green algal cells. J. Biol. Chem. 280, 34170. 
Kumar, K., Mishra, S.K., Shrivastav, A., Park, M.S., and Yang, J.-W. (2015). Recent trends in the mass cultivation of algae in raceway ponds. Renew. Sust. Energy. Rev. 51, 875.

Kumar, K.S., Dahms, H.U., Won, E.J., Lee, J.S., and Shin, K.H. (2015). Microalgae-A promising tool for heavy metal remediation. Ecotoxicol. Environ. Saf. 113, 329.

Laurinavichene, T.V., Kosourov, S.N., Ghirardi, M.L., Seibert, M., and Tsygankov, A.A. (2008). Prolongation of $\mathrm{H}_{2}$ photoproduction by immobilized, sulfur-limited Chlamydomonas reinhardtii cultures. J. Biotechnol. 134, 275.

Lee, S.J., Hawkins, T.R., Ingwersen, W.W., and Young, D.M. (2015). Exploring the use of ecological footprint in life cycle impact assessment. J. Ind. Ecol. 19, 416.

Lee, Y.-H., and Yeh, Y.-L. (2015). Reduction of oxygen inhibition effect for microalgal growth using fluoroalkylated methoxy polyethylene glycol-stabilized perfluorocarbon nano-oxygen carriers. Process Biochem. 50, 1119.

Li, R., Chen, G.-Z., Tam, N.F.Y., Luan, T.-G., Shin, P.K., Cheung, S.G., and Liu, Y. (2009). Toxicity of bisphenol A and its bioaccumulation and removal by a marine microalga Stephanodiscus hantzschii. Ecotoxicol. Environ. Saf. 72, 321.

Liang, K., Zhang, Q., Gu, M., and Cong, W. (2013). Effect of phosphorus on lipid accumulation in freshwater microalga Chlorella sp. J. Appl. Phycol. 25, 311.

Liu, X., Saydah, B., Eranki, P., Colosi, L.M., Mitchell, B.G., Rhodes, J., and Clarens, A.F. (2013). Pilot-scale data provide enhanced estimates of the life cycle energy and emissions profile of algae biofuels produced via hydrothermal liquefaction. Bioresour. Technol. 148, 163.

Liu, Y., Wang, F., Chen, X., Zhang, J., and Gao, B. (2015). Cellular responses and biodegradation of amoxicillin in $\mathrm{Mi}-$ crocystis aeruginosa at different nitrogen levels. Ecotoxicol. Environ. Saf. 111, 138.

Liu, Z.-Y., Wang, G.-C., and Zhou, B.-C. (2008). Effect of iron on growth and lipid accumulation in Chlorella vulgaris. Bioresour. Technol. 99, 4717.

Logan, B.E. (2008). Microbial Fuel Cells. John Wiley \& Sons, Hoboken, NJ, USA.

Logan, B.E., Hamelers, B., Rozendal, R., Schröder, U., Keller, J., Freguia, S., Aelterman, P., Verstraete, W., and Rabaey, K. (2006). Microbial fuel cells: Methodology and technology. Environ. Sci. Technol. 40, 5181.

Lundquist, T.J., Woertz, I.C., Quinn, N.W.T., and Benemann, J.R. (2010). A realistic technology and engineering assessment of algae biofuel production. Energ. Biosci. Inst. 1, 84.

Macedo R.V.T., Alegre R.M. (2001). Influence of nitrogen content in the cultivation of Spirulina maxima in two temperature levels-Part II, Produção de Lipídios Ciênc. $\underline{\text { Tecnol. }}$ Aliment. Campinas. 21, 183.

Matamoros, V., Gutiérrez, R., Ferrer, I., García, J., and Bayona, J.M. (2015). Capability of microalgae-based wastewater treatment systems to remove emerging organic contaminants: a pilot-scale study. J. Hazard. Mat. 288, 34 .

Mehlitz, T.H. (2009). Temperature influence and heat management requirements of microalgae culivation in photobioreactors. [MS Thesis]. San Luis Obispo (CA): California Polytechnic State University.

Melis, A., Zhang, L., Forestier, M., Ghirardi, M.L., and Seibert, M. (2000). Sustained photobiological hydrogen gas production upon reversible inactivation of oxygen evolution in the green alga chlamydomonas reinhardtii. Plant Physiol. $122,127$.

Metting, F. (1996). Biodiversity and application of microalgae. J. Ind. Microbiol. 17, 477.
Middelboe, A., and Juel Hansen, P. (2007). Direct effects of pH and inorganic carbon on macroalgal photosynthesis and growth. Mar. Biol. Res. 3, 134.

Milledge, J.J., and Heaven, S. (2013). A review of the harvesting of micro-algae for biofuel production. Rev. Environ. Sci. Biotechnol. 12, 165.

Miranda, J., Passarinho, P.C., and Gouveia, L. (2012). Pretreatment optimization of Scenedesmus obliquus microalga for bioethanol production. Bioresour. Technol. 104, 342.

Moheimani, N.R. (2005). The culture of coccolithophorid algae for carbon dioxide bioremediation. [PhD Thesis]. Murdoch (Australia): Murdoch University.

Mohn, F.H. (1988). Harvesting of microalgal biomass. In Borowitzka, M.A., and Borowitzka L.J. Eds. Microalgal Biotechnology. Cambridge: Cambridge University Press, p. 395.

Monteiro, C.M., Castro, P.M., and Malcata, F.X. (2012). Metal uptake by microalgae: Underlying mechanisms and practical applications. Biotechnol. Prog. 28, 299.

Mooij, P.R., Stouten, G.R., van Loosdrecht, M.C., and Kleerebezem, R. (2015). Ecology-based selective environments as solution to contamination in microalgal cultivation. Curr. Opin. Biotechnol. 33, 46.

Moore, A. (2008). Biofuels are dead: Long live biofuels (?)Part one. N. Biotechnol. 25, 6.

Mu, D., Min, M., Krohn, B., Mullins, K.A., Ruan, R., and Hill, J. (2014). Life cycle environmental impacts of wastewaterbased algal biofuels. Environ. Sci. Technol. 48, 11696.

Mulbry, W., Kondrad, S., Pizarro, C., and Kebede-Westhead, E. (2008). Treatment of dairy manure effluent using freshwater algae: Algal productivity and recovery of manure nutrients using pilot-scale algal turf scrubbers. Bioresour. Technol. 99, 8137.

Nascimento, I.A., Marques, S.S.I., Cabanelas, I.T.D., Pereira, S.A., Druzian, J.I., de Souza, C.O., Vich, D.V., Carvalho, G.C., and Nascimento, M.A. (2013). Screening microalgae strains for biodiesel production: lipid productivity and estimation of fuel quality based on fatty acids profiles as selective criteria. Bioenerg. Res. 6, 1.

Norvill, Z.N., Shilton, A., and Guieysse, B. (2016). Emerging contaminant degradation and removal in algal wastewater treatment ponds: Identifying the research gaps. J. Hazard. Mater. 313, 291.

Oh, H.-M., Lee, S.J., Park, M.-H., Kim, H.-S., Kim, H.-C., Yoon, J.-H., Kwon, G.-S., and Yoon, B.-D. (2001). Harvesting of Chlorella vulgaris using a bioflocculant from Paenibacillus sp. AM49. Biotechnol. Lett. 23, 1229.

Or-Rashid, M., Kramer, J., Wood, M., and McBride, B. (2008). Supplemental algal meal alters the ruminal trans-18: 1 fatty acid and conjugated linoleic acid composition in cattle. $\underline{J}$. Anim. Sci. 86, 187.

Oswald, W.J., and Golueke, C.G. (1960). Biological transformation of solar energy. Adv. Appl. Microbiol. 2, 223.

Pahl, S.L., Lee, A.K., Kalaitzidis, T., Ashman, P.J., Sathe, S., and Lewis, D.M. (2013). Harvesting, thickening and dewatering microalgae biomass. In Borowitaka, M.A., and Moheimani, N.R. Eds. Algae for Biofuels and Energy. Netherlands: Springer. p. 165.

Papazi, A., Makridis, P., and Divanach, P. (2010). Harvesting Chlorella minutissima using cell coagulants. J. Appl. Phycol. 22, 349.

Park, J., Craggs, R., and Shilton, A. (2011). Wastewater treatment high rate algal ponds for biofuel production. Bioresour. Technol. 102, 35.

Passell, H., Dhaliwal, H., Reno, M., Wu, B., Amotz, A.B., Ivry, E., Gay, M., Czartoski, T., Laurin, L., and Ayer, N. (2013). 
Algae biodiesel life cycle assessment using current commercial data. J. Environ. Manage. 129, 103.

Passos, F., Uggetti, E., Carrere, H. and Ferrer, I. (2014). Pretreatment of microalgae to improve biogas production: A review. Bioresour. Technol. 172, 403.

Pittman, J.K., Dean, A. P., and Osundeko, O. (2011). The potential of sustainable algal biofuel production using wastewater resources. Bioresour. Technol. 102, 17.

Ponnusamy, S., Reddy, H.K., Muppaneni, T., Downes, C.M., and Deng, S. (2014). Life cycle assessment of biodiesel production from algal bio-crude oils extracted under subcritical water conditions. Bioresour. Technol. 170, 454.

Powell, N., Shilton, A.N., Pratt, S., and Chisti, Y. (2008). Factors influencing luxury uptake of phosphorus by microalgae in waste stabilization ponds. Environ. Sci. Technol. 42, 5958.

Prince, R.C., and Kheshgi, H.S. (2005). The photobiological production of hydrogen: Potential efficiency and effectiveness as a renewable fuel. Crit. Rev. Microbiol. 31, 19.

Pruvost, J., Cornet, J.-F., and Pilon, L. (2016). Large-scale production of algal biomass: Photobioreactors. Algae Biotechnol. 41.

Pulz, O. (2001). Photobioreactors: Production systems for phototrophic microorganisms. Appl. Microbiol. Biotechnol. 57, 287.

Quinn, J.C., and Davis, R. (2015). The potentials and challenges of algae based biofuels: A review of the techno-economic, life cycle, and resource assessment modeling. Bioresour. Technol. 184, 444.

Quinn, J.C., Smith, T.G., Downes, C.M., and Quinn, C. (2014). Microalgae to biofuels lifecycle assessment-multiple pathway evaluation. Algal Res. 4, 116.

Quinn, J.C., Yates, T., Douglas, N., Weyer, K., Butler, J., Bradley, T.H., and Lammers, P.J. (2012). Nannochloropsis production metrics in a scalable outdoor photobioreactor for commercial applications. Bioresour. Technol. 117, 164.

Rai, L., and Mallick, N. (1992). Removal and assessment of toxicity of $\mathrm{Cu}$ and $\mathrm{Fe}$ to Anabaena doliolum and Chlorella vulgaris using free and immobilized cells. World J. Microbiol. Biotechnol. 8, 110.

Richards R.G., Mullins B.J. (2013). Using microalgae for combined lipid production and heavy metal removal from leachate. Ecol. Model. 249, 59.

Richardson, J.W., Johnson, M.D., and Outlaw, J.L. (2012). Economic comparison of open pond raceways to photo bioreactors for profitable production of algae for transportation fuels in the Southwest. Algal Res. 1, 93.

Rodríguez, M.R., De Ruyck, J., Díaz, P.R., Verma, V.K., and Bram, S. (2011). An LCA based indicator for evaluation of alternative energy routes. Appl. Energy. 88, 630.

Rosenbaum, M., He, Z., and Angenent, L.T. (2010). Light energy to bioelectricity: Photosynthetic microbial fuel cells. Curr. Opin. Biotechnol. 21, 259.

Rosso, D., Stenstrom, M., and Larson, L. (2008). Aeration of large-scale municipal wastewater treatment plants: State of the art. Water Sci. Technol. 57, 973.

Schenk, P., Thomas-Hall, S., Stephens, E., Marx, U., Mussgnug, J., Posten, C., Kruse, O., and Hankamer, B. (2008). Second generation biofuels: High-efficiency microalgae for biodiesel production. BioEnergy Res. 1, 20.

Sharma, K.K., Garg, S., Li, Y., Malekizadeh, A., and Schenk, P.M. (2013). Critical analysis of current microalgae dewatering techniques. Biofuels 4, 397.

Sharma, K.K., Schuhmann, H., and Schenk, P.M. (2012). High lipid induction in microalgae for biodiesel production. Energies, 5, 1532.
Shirvani, T., Yan, X., Inderwildi, O.R., Edwards, P.P., King, D.A. (2011). Life cycle energy and greenhouse gas analysis for algae-derived biodiesel. Energy Environ. Sci. 4, 3773.

Shuping, Z., Yulong, W., Mingde, Y., Kaleem, I., Chun, L., and Tong, J. (2010). Production and characterization of bio-oil from hydrothermal liquefaction of microalgae Dunaliella tertiolecta cake. Energ. 35, 5406.

Sills, D.L., Paramita, V., Franke, M.J., Johnson, M.C., Akabas, T.M., Greene, C.H., Tester, J.W. (2013). Quantitative uncertainty analysis of life cycle assessment for algal biofuel production. Environ. Sci. Technol. 47, 687.

Sivakumar, G., Xu, J., Thompson, R.W., Yang, Y., RandolSmith, P., and Weathers, P.J. (2012). Integrated green algal technology for bioremediation and biofuel. Bioresour. Technol. 107,1 .

Soh, L., Montazeri, M., Haznedaroglu, B.Z., Kelly, C., Peccia, J., Eckelman, M.J., and Zimmerman, J.B. (2014). Evaluating microalgal integrated biorefinery schemes: Empirical controlled growth studies and life cycle assessment. Bioresour. Technol. 151, 19.

Sun, A., Davis, R., Starbuck, M., Ben-Amotz, A., Pate, R., and Pienkos, P.T. (2011). Comparative cost analysis of algal oil production for biofuels. Energy 36, 5169.

Suresh, K.K, Dahms H.-U., Won, E.-J., Lee, J.-S., and Shin, K.-H. (2015). Microalgae-A promising tool for heavy metal remediation. Ecotoxicol. Environ. Saf. 113, 329.

Thomas W.H., Tornabene T.G., and Weissman J. (1984). Screening for lipid yielding microalgae: Activities for 1983. SERI/STR-231-2207.

Uduman, N., Qi, Y., Danquah, M.K., Forde, G.M., and Hoadley A. (2010). Dewatering of microalgal cultures: A major bottleneck to algae-based fuels. J. Renew. Sust. Energy 2, 012701.

Van Den Hende, S., Vervaeren, H., Desmet, S., and Boon, N. (2011). Bioflocculation of microalgae and bacteria combined with flue gas to improve sewage treatment. $N$. Biotechnol. 29, 23.

Van Wagenen, J., Holdt, S.L., De Francisci, D., Valverde-Pérez, B., Plósz, B.G., and Angelidaki, I. (2014). Microplate-based method for high-throughput screening of microalgae growth potential. Bioresour. Technol. 169, 566.

Vandamme, D., Pontes, S.C.V., Goiris, K., Foubert, I., Pinoy, L.J.J., and Muylaert, K. (2011). Evaluation of electrocoagulation-flocculation for harvesting marine and freshwater microalgae. Biotechnol. Bioeng. 108, 2320.

Vasudevan, V., Stratton, R.W., Pearlson, M.N., Jersey, G.R., Beyene, A.G., Weissman, J.C., Rubino, M., and Hileman, J.I. (2012). Environmental performance of algal biofuel technology options. Environ. Sci. Technol. 46, 2451.

Vijayaraghavan, K., Karthik, R., and Nalini, S.K. (2010). Hydrogen generation from algae: A review. J. Plant Sci. 5, 1.

Wang, M., Yang, H., Ergas, S.J., van der Steen, P. (2015). A novel shortcut nitrogen removal process using an algalbacterial consortium in a photo-sequencing batch reactor (PSBR). Water Res. 87, 38.

Warabi, Y., Kusdiana, D., and Saka, S. (2004). Reactivity of triglycerides and fatty acids of rapeseed oil in supercritical alcohols. Bioresour. Technol. 91, 283.

Ward, A.J., Lewis, D.M., and Green, F.B. (2014). Anaerobic digestion of algae biomass: A review. Algal Res. 5, 204.

Wen, Z., Liao, W., and Chen, S. (2004). Hydrolysis of animal manure lignocellulosics for reducing sugar production. Bioresour. Technol. 91, 31.

Woertz, I.C., Benemann, J.R., Du, N., Unnasch, S., Mendola, D., Mitchell, B.G., and Lundquist, T.J. (2014). Life cycle 
GHG emissions from microalgal biodiesel-a CA-GREET model. Environ. Sci. Technol. 48, 6060.

Xin, L., Hong-Ying, H., and Jia, Y. (2010). Lipid accumulation and nutrient removal properties of a newly isolated freshwater microalga, Scenedesmus sp. LX1, growing in secondary effluent. N. Biotechnol. 27, 59.

Xu, L., Brilman, D.W.W., Withag, J.A., Brem, G., and Kersten, S. (2011). Assessment of a dry and a wet route for the production of biofuels from microalgae: Energy balance analysis. Bioresour. Technol. 102, 5113.

Yang, J., Xu, M., Zhang, X., Hu, Q., Sommerfeld, M., and Chen, Y. (2011). Life-cycle analysis on biodiesel production from microalgae: Water footprint and nutrients balance. Bioresour. Technol. 102, 159.

Yuan, X., Wang, J., Zeng, G., Huang, H., Pei, X., Li, H., Liu, Z and Cong, M. (2011). Comparative studies of thermochemical liquefaction characteristics of microalgae using different organic solvents. Energ. 36, 6406.

Zhao, G., Chen, X., Wang, L., Zhou, S., Feng, H., Chen, W.N., and Lau, R. (2013). Ultrasound assisted extraction of carbohydrates from microalgae as feedstock for yeast fermentation. Bioresour. Technol. 128, 337.

Zhou, W., Li, Y., Min, M., Hu, B., Chen, P., and Ruan, R. (2011). Local bioprospecting for high-lipid producing microalgal strains to be grown on concentrated municipal wastewater for biofuel production. Bioresour. Technol. 102, 6909.

Zhou, W., Li, Y., Min, M., Hu, B., Zhang, H., Ma, X., Li, L., Cheng, Y., Chen, P., and Ruan, R. (2012). Growing wastewater-born microalga Auxenochlorella protothecoides UMN280 on concentrated municipal wastewater for simultaneous nutrient removal and energy feedstock production. Appl. Energy 98, 433. 


\section{This article has been cited by:}

1. Jie Xu, Xue Wang, Shiqing Sun, Yongjun Zhao, Changwei Hu. 2017. Effects of influent C/N ratios and treatment technologies on integral biogas upgrading and pollutants removal from synthetic domestic sewage. Scientific Reports 7:1. . [Crossref]

2. Yinghui Wang, Junzhuo Liu, Du Kang, Chenxi Wu, Yonghong Wu. 2017. Removal of pharmaceuticals and personal care products from wastewater using algae-based technologies: a review. Reviews in Environmental Science and Bio/Technology 16:4, 717-735. [Crossref]

3. Joo-Young Jung, Jim Hyacinth Damusaru, Youngjin Park, Kyochan Kim, Minji Seong, Hyeong-Woo Je, Soohwan Kim, Sungchul C. Bai. 2017. Autotrophic biofloc technology system (ABFT) using Chlorella vulgaris and Scenedesmus obliquus positively affects performance of Nile tilapia ( Oreochromis niloticus ). Algal Research 27, 259-264. [Crossref]

4. Jared Church, Jae-Hoon Hwang, Keug-Tae Kim, Rebecca McLean, You-Kwan Oh, Bora Nam, Jin Chul Joo, Woo Hyoung Lee. 2017. Effect of salt type and concentration on the growth and lipid content of Chlorella vulgaris in synthetic saline wastewater for biofuel production. Bioresource Technology 243, 147-153. [Crossref]

5. P. Young, M. Taylor, H. J. Fallowfield. 2017. Mini-review: high rate algal ponds, flexible systems for sustainable wastewater treatment. World Journal of Microbiology and Biotechnology 33:6. . [Crossref]

6. Elena Gogina, Olga Ruzhitskaya. 2017. Modern technologies of the removal of nutrients from sewage and the study of microbiological processes in their application. MATEC Web of Conferences 106, 07001. [Crossref]

7. Olga Ruzhitskaya, Elena Gogina. 2017. Methods for Removing of Phosphates from Wastewater. MATEC Web of Conferences 106, 07006. [Crossref]

8. Ergas Sarina J., Kinyua Maureen N., van der Steen Peter, Butler Caitlyn S., Lens Piet N.L., Chandran Kartik, Mihelcic James R.. 2016. Innovative Global Solutions for Bioenergy Production. Environmental Engineering Science 33:11, 841-842. [Citation] [Full Text HTML] [Full Text PDF] [Full Text PDF with Links] 